\title{
Promissory Fraud and the Parol Evidence Rule
}

Justin Sweet*

$T^{\mathrm{T}}$ Is generally agreed that the parol evidence rule does not prevent admis1 sion of evidence of fraud. This principle is sometimes erroneously described as an exception to the rule, a characterization that has led to considerable confusion. Basically, the integration aspect of the parol evidence rule is inapplicable unless there is a validly formed contract embodied in a writing that is assented to by the parties as the final repository of their entire agreement. Without valid formation, there is no contract to be protected by the exclusion of extrinsic evidence. The existence of fraud constitutes a material defect in the formation of the contract, and evidence of defective formation is admissible. However, when the fraud consists of an oral promise made without an intent to render the promised performance, the authorities diverge. This article will analyze the existing California law and present some suggestions for future treatment of cases where the parol evidence rule and claims of promissory fraud are in apparent conflict.

The present California rules are derived from Bank of America Nat'l Trust \& Sav. Ass'n v. Pendergrass, ${ }^{1}$ decided in 1935. The Supreme Court of California stated that evidence of a promise made without any intention of performing it was inadmissible, where the alleged false promise was "in direct contravention of the unconditional promise" contained in the written contract in question.

The holding gives rise to several questions, of which this article will attempt to answer the following:

1. Was the Pendergrass case based upon either precedent or sound policy considerations?

2. Should any limitations be placed upon evidence of promissory fraud?

3. Once fraud is established by evidence outside the writing, to what remedies should the innocent party be entitled?

* Associate Professor of Law, University of California School of Law, Berkeley.

14 Cal. 2d 258, 48 P.2d 659 (1935).

2Id. at $263,48 \mathrm{P} .2 \mathrm{~d}$ at 661 . 
THE CAIIFORNIA LAW ON PROMISSORY FRAUD AND THE PAROL EVIDENCE RULE

\section{A. The Pendergrass Case}

In 1932 Pendergrass and his son were deeply in debt to the Bank of America. They had purchased a ranch in 1928 subject to a $\$ 20,000$ trust deed, and had borrowed an additional $\$ 14,750$ without giving security. In January 1932, the bank apparently threatened to foreclose the deed of trust unless additional security was provided by the Pendergrasses. Negotiations took place, and the bank was given crop and chattel mortgages and a new demand note for $\$ 4,750$, representing a portion of the previously unsecured debt. Within a short time after the execution of these documents the bank demanded payment, and when none was forthcoming, seized all the property covered by the mortgages.

The bank then started an action on the $\$ 4,750$ note. Two defenses were raised by defendants' answer: (1) that since the note was secured by a chattel mortgage, the bank could enforce it only by judicial foreclosure, and (2) that the note was obtained by fraud. At the ensuing jury trial, the plaintiff offered the note and testimony that it had not been paid, and rested its case.

Defendants' attorney then made his opening statement to the jury. He described the negotiations leading to the execution of the note and the chattel inortgage. In particular, he stated that the representatives of the bank promised that if defendants executed the note and inortgage, "they would not be required 'to make any payments on their indebtedness ..."' until the 1932 crop was in, and that "the bank would permit them to go ahead and operate and produce this 1932 crop." "3 He claimed that these promises were made without any intention of performing them, solely for the purpose of obtaining the note and mortgage The defendants, he said, relied on these false promises and executed the note being sued upon. Whether the jury was inipressed, we have no way of knowing; the trial judge was not: he directed judgment for plaintiff at the conclusion of the defendants' opering statement.

The Pendergrasses reasserted their defenses in the district court of appeal. ${ }^{4}$ The defense that the note was secured and could only be enforced by judicial foreclosure ${ }^{5}$ apparently had failed in the trial court because

\section{Ibid.}

4 Bank of America Nat'l Trust \& Sav. Ass'n v. Pendergrass, 35 P.2d 346 (1934).

5 Western Fuel Co. v. S. G. Lewald Co., 190 Cal. 25, 27, 210 Pac. 419, 420 (1922); CAt. Cone Crv. Proc. $\$ 726$. 
of a pleading error, which the appeal court determined had been cured by the opening statement. On this ground it reversed the judgment.

The court then went on to discuss the question raised by the defense of promissory fraud. Presumably it felt that because of existing economic conditions this was a matter requiring comment, even if not crucial to the case. It concluded that promissory fraud could be used as a defense.

The Supreme Court of California disagreed. Even though the case had been reversed on the foreclosure issue, the supreme court was not willing to allow the intermediate appellate court's comments on promissory fraud to stand. It granted a hearing and adopted verbatim most of the lower court's opimion, except for the portion dealing with fraud. ${ }^{6}$ Perhaps it, too, was aware of the gravity of the problem in the light of the depression and debtor-oriented juries. Whatever its unstated motivation, the court ignored the district court's reference to the California Civil Code, which recognizes a false promise as fraud, ${ }^{7}$ ignored the cases relied upon below, and instead followed an early Virginia case, Towner v. Lucas' Ex'r. The supreme court posed the question involved and answered it without hesitation:

Is such a promise the subject of parol proof for the purpose of establisling fraud as a defense to the action or by way of cancelling the note, assuming, of course, that it can be properly coupled with proof that it was made without any intention of performing it? Our conception of the rule which permits parol evidence of fraud to establish the invalidity of the instrument is that it must tend to establish some independent fact or representation, some fraud in the procurement of the instrument or some breach of confidence concerning its use, and not a promise directly at variance with the promise of the writing. ${ }^{\circ}$

The court reiterated that if the alleged oral promise is at variance with the writing, evidence of the promise is madmissible, despite the allegation that it was made without an intent to perform.

This qualification is not imposed by section 238 of the Restatement of Contracts:

Agreements prior to or contemporaneous with an integration are admissible in evidence

(b) to prove facts rendering the agreement void or voidable for illegality, fraud, duress, mistake or insufficiency of consideration. ${ }^{10}$

${ }^{6}$ Bank of America Nat'l Trust \& Sav. Ass'n v. Pendergrass, 4 Cal. 2d 258, 48 P.2d 659 (1935).

7 CAI. Civ. CoDe $\$ \$ 1572,1710$.

854 Va. (13 Gratt.) 705 (1857).

${ }^{4} 4 \mathrm{Cal} .2 \mathrm{~d}$ at 263,48 P.2d at 661 . (Emphasis added.)

10 Restatement, Contracts $\$ 238$ (b) (1932). 
Furthermore, Corbin, perhaps overenthusiastically, denies any effect to mconsistency, stating that: "[I]t is in no case denied that oral testimony is admissible to prove fraud, illegality, accident or mistake. This is so, even though the testimony contradicts the terms of a complete integration in writing."11

\section{B. California Law Prior to Pendergrass}

\section{The California Codes}

Section 1856 of the Code of Civil Procedure states:

When the terms of an agreement have been reduced to writing by the parties, it is to be considered as containing all those terms, and therefore there can be between the parties and their representatives, or successors in interest, no evidence of the terms of the agreement other than the contents of the writing, except in the following cases:

1. Where a mistake or imperfection of the writing is put in issue by the pleadings;

2. Where the validity of the agreement is the fact in dispute.

But this section does not exclude other evidence of the circumstances under which the agreement was made or to which it relates ... or to explain an extrinsic ambiguity, or to establish illegality or fraud. The term agreement includes deeds and wills, as well as contracts between parties. [Emphasis adder.]

The notes of the Code Commissioners declare that "parol evidence was held inadmissible ... to contradict the recital ... though such evidence may be admitted to show a fraud in the sale."12 The corresponding section of the Civil Code is section 1625, which does not mention fraud. But in the Code Conmissioners' note on that section there is a statement that "stipulations are merged in the writing, and in the absence of fraud, accident, or mistake, the writing is the exclusive medium of ascertaining the agreement to which the parties bound themselves."13 The Commissioners cited an 1863 California case that recognizes, in dictum, the admissibility of evidence of fraud. ${ }^{14}$

Certainly there is nothing in the codes or pre-code California cases that would indicate a requirement that promissory fraud be treated more stringently than fraud involving a misrepresentation of an existing fact. Section 1856 of the Code of Civil Procedure clearly recognizes that proof of fraud is admissible without qualification and sections 1572 and 1710

113 Corbin, Contracts $\$ 580$ (1960); see Dawson \& Patamer, Cases on Restitution 275 (1958).

12 Cal. Code Crv. Proc. $\$ 1856$, Code Commissioners' Note at 806 (Deering 1954), citing Donahue v. McNulty, 24 Cal. 418 (1864).

13 Cat. Crv. Code AnN. § 1625, Notes (Bancroft 1874).

14 Goldman v. Davis, 23 Cal. 256 (1863). 
of the Civil Code both state that fraud may consist of a "promise made without any intention of performing it." The requirement set forth in the Pendergrass case is not to be found in the codes.

\section{Case Law}

Although most of the relevant cases prior to Pendergrass involved misrepresentations of fact, there was nothing in them that would indicate a stricter rule in promissory fraud cases. A number involve oral promises that were inconsistent with the writing and contain the usual dicta that a different result would have obtained had fraud been alleged..$^{15}$

Where evidence of promissory fraud was admitted, the oral promises were usually not at variance with those contained in the writing. ${ }^{16} \mathrm{~A}$ few were warranty cases. ${ }^{17}$ One case admitted the alleged oral promise, even though an integration clause made any promises not contained in the

15 See, e.g., Lompoc Valley Bank v. Stephenson, 156 Cai. 350, 104 Pac. 449 (1909); Harrison v. McCormick, 89 Cal. 327, 26 Pac. 830 (1891); Consolidated Lumber Co. v. Frew, 32 Cal. App. 118, 162 Pac. 430 (1916).

16 Graham v. Los Angeles First Nat'l Trust \& Sav. Bank, 3 Cal. 2d 37, 43 P.2d 543 (1935) (sale of land; oral promise of improvements without expense to buyers, parol evidence rule not mentioned); Paohni v. Sulprizio, 201 Cal. 683, 258 Pac. 380 (1927) (warranty of nature and quality of land sold); Newman v. Smith, 77 Cal. 22, 18 Pac. 791 (1888) (sale of land; oral promise to use louse as home for persons interested in spiritualism); Boulevard Land Co. v. King, 125 Cal. App. 224, 13 P.2d 864 (1932) (sale of land; oral promise to resell at profit); Wiberg v. Barnum, $99 \mathrm{Cal}$. App. 323, 278 Pac. 871 (1929) (sale of land; oral promise to resell at profit); Bouey v. Porterfield, 96 Cal. App. 674, 274 Pac. 766 (1929) (sale of stock; oral promise to repurchase).

Many of these cases could be justified on the consistent collateral contract or partial integration theory without resort to fraud. See Crawford v. France, 219 Cal. 439, 27 P.2d 645 (1933); Sivers v. Sivers, 97 Cal. 518, 32 Pac. 571 (1893); Greathouse v. Delano, 57 Cal. App. 187, 206 Pac. 1019 (1922).

17 E.g., American Soda \& Fountain Co. v. Martin, 100 Cal. App. 43, 279 Pac. 680 (1929) (sale of freezer; oral warranty of operation).

As I use the term "warranty," it means a promise that something will happen in the future, usually without the necessity of further perfornance by the promisor. For example, a car dealer selling a used automobile may represent that:

1. The car was overhauled a month ago.

2. The car will get 20 miles per gallon.

3. The car will operate trouble-free for 90 days.

4. The seller will put in a radio within two weeks.

The buyer may rely upon all these statements. The first is clearly a statement of fact. The second, if it is not merely a statement of opinion or seller's talk, is a warranty. Note that the seller does not promise to do anything, but if the car does not perform as promised, the buyer will have the remedies allowed by law. This representation might be considered a statement of fact that the car at the time of sale gets 20 miles to the gallon. The third looks like a warranty, but this is more likely to be an impled promise that if something goes wrong with the car, the seller will repair it. The fourth is clearly a promise. The term warranty is used in all four situations, and quite commonly in the first three. Analytically, all but the first are promises, as promises are defined in the Restatemant of Contracts $\$ 2$ comment $a$ (1932). Yet at times the courts treat warranties differently from promises. 
writing inconsistent. ${ }^{18}$ Others admitted evidence of oral promises, though they were inconsistent by implication. ${ }^{19}$

Langley $v$. Rodrigue ${ }^{20}$ deserves special mention. The assignee of a packing company brought an action for damages against a grape grower who had entered into a written crop contract with the packer. In defense, the grower claimed that the packer's agent liad induced lim to contract by orally promising an advance payment. This contradicted the terms of the contract, which specified that payment would be made only upon delivery of the crop. The trial court rejected this evidence of fraud, but the supreme court reversed, stating that:

The [parol evidence] rule cannot be avoided by showing that the promise outside the writing has been broken; such breach in itself does not constitute fraud .... [citing cases] But a promise made without any intention of performing it is one of the forms of actual fraud (Civ. Code, sec. 1572); and cases are not infrequent where relief against a contract reduced to writing has been granted on the ground that its execution was procured by means of oral promises fraudulent in the particular mentioned, however variant from the terms of the voritten engagement into which they were the uneans of inveigling the party. ${ }^{21}$

A 1919 district court of appeal case, $Y u b a M f g$. Co. v. Stone, ${ }^{22}$ did seein to establisl a different rule for sales warranty cases, apparently requiring fraud in the execution where there was a writing. Y $u b a$ was cited in a subsequent case that discussed the problem in terms of a variation in the writing, ${ }^{23}$ but neither of these cases was influential, and $Y u b a$ was in effect overruled by the Supreme Court of California in 1928. ${ }^{24}$

Occasionally, the court displayed a reluctance to recognize that a promise made without intention of performing it could be fraud, despite the clear langnage of section 1572 and 1710 of the Civil Code. ${ }^{25}$ Nevertheless, the law prior to the Pendergrass case, despite occasional waverings,

18 Blackwell v. Thomasson, 84 Cal. App. 784, 258 Pac. 724 (1927).

${ }^{19}$ Stewart v. Crowley, 213 Cal. 694, 3 P.2d 562 (1931) (lease; oral promise to surrender lease if lessor sold property); Bouey v. Porterfield, 96 Cal. App. 674, 274 Pac. 766 (1929) (sale of stock; oral promise to repurchase); Grinnell v. Hill, 1 Cal. App. 492, 82 Pac. 445 (1905) (oral promise not to enforce note given in stock purchase).

20122 Cal. 580, 55 Pac. 406 (1898); Langley was completely misunderstood in Eade v. Reich, 120 Cal. App. 32, 7 P.2d 1043 (1932), where it was interpreted to require a fact representation.

21 Langley v. Rodriguez, 122 Cal. 580, 581-82, 55 Pac. 406, 407 (1898). (Emphasis added.) See Williams v. Hasshagen, 166 Cal. 386, 137 Pac. 9 (1913).

2239 Cal. App. 440, 179 Pac. 418 (1919).

23 W. C. Campbell v. Sears, Roebuck \& Co., 136 Cal. App. 765, 29 P.2d 910 (1934).

24 Ferguson v. Koch, 204 Cal. 342, 268 Pac. 342 (1928).

25 California Credit \& Collection Corp. v. Carpenter, 77 Cal. App. 18, 246 Pac. 126 (1926). See also, Eade v. Reicb, 120 Cal. App. 32, 7 P.2d 1043 (1932), supra note 20. 
did not require that the alleged oral promise be consistent with the writing when fraud was alleged.

\section{The Basis for the Pendergrass Holding}

It is interesting to examine the authorities relied upon by the parties in Pendergrass. The defendants cited the Civil Code sections stating that a promise made without intention of performing it is fraud, ${ }^{26}$ and two cases. One concerned an additional promise, which had been construed to be a statement of present fact. ${ }^{27}$ The other involved both false representations of fact and an oral promise to repurchase; the writing specified an absolute sale, so that the oral promise was by implication inconsistent. ${ }^{28}$ Neither case dealt solely with a promise inconsistent with the writing. Langley $v$. Rodriguez was not brought to the attention of the court.

The bank cited a number of cases in which fraud was either not in issue or not alleged, ${ }^{29}$ including one that expressly stated that no fraud had been alleged. ${ }^{30}$ For the most part, the bank's brief was devoted to a lengthy quotation from Wigmore. In a rather opaque passage, Wigmore states that fraud carmot be predicated upon a promise made without intention of performing. ${ }^{31}$ This is clearly contrary to the law of California enunciated in the Code, ${ }^{32}$ and even in 1935 did not represent the view of the majority of courts in this country. ${ }^{33}$

The brief went on to cite another district court of appeal opinion that paraphrased with approval Wigmore's statement that a false promise could not be the basis of fraud. ${ }^{34}$ The court in that case stressed that serious harm would result from extending the fraud "exception" to situations in which the party could protect himself by getting the promise in writing. The case, however, did not involve fraud.

How did the Pendergrass court justify its conclusion that in promissory fraud cases the alleged oral promise must not be inconsistent with the

28 Brief for Appellant, pp. 11-12.

27 Bouey v. Porterfield, 96 Cal. App. 674, 274 Pac. 766 (1929).

28 California Credit \& Collection Corp. v. Carpenter, 77 Cal. App. 18, 246 Pac. 766 (1929).

29 McArthur v. Johnson, 216 Cal. 580, 15 P.2d 151 (1932); Harding v. Robinson, $175 \mathrm{Cal}$. 534, 166 Pac. 808 (1917); Pierce v. Avakian, 167 Cal. 330, 139 Pac. 799 (1914); Rottman v. Hevener, 54 Cal. App. 474, 202 Pac. 329 (1921); Thounson v. Langton, 45 Cal. App. 415, 187 Pac. 970 (1920).

30 Rottman v. Hevener, supra note 29 , at 478,202 Pac. at 331 .

319 WigAroRE, EvIDENCE $\$ 2439$ (3d ed. 1940).

32 CAI. Crv. CoDE $\$ \S 1572,1710$. One argument might be made against this conclusion. Perhaps the Code sections defining fraud to include promissory fraud could be restricted to situations that did not involve a clash with the parol evidence rule. If so, fraud, as used in CAI. Code Crv. Proc. $\S 1856$, could be himited to mean only fraud based on misrepresentation of fact, conforming with 9 WIGMORE, op. cit. supra note $31, \$ 2439$.

33 See Prosser, Torts 564 (2d ed. 1955).

34 Lindemann v. Coryell, 59 Cal. App. 788, 212 Pac. 47 (1922). 
writing? It cited Towner v. Lucas' Ex'r ${ }^{35}$ an 1857 Virginia case. Lucas had signed three bonds as surety, and Towner, the holder of the bonds, had taken default judgments against him when the primary debtors had failed to pay. Lucas claimed Towner had promised "that if Lucas would sign said bonds he should never be required to pay any part of the debt, and that he would give Lucas his written indemnity so as to save him harmless." ${ }^{36}$ In reliance on this oral promise, Lucas signed the bonds and allowed the judgments to be entered against him. When Towner failed to deliver the promised indemnity, Lucas filed a bill in equity to enjoin Towner from enforcing the judgments. The trial court enjoined Towner but on appeal the decree was reversed. The appellate court recognized that evidence of fraud was admissible to show a defect in formation, but noted that no fraud was alleged in the bill. ${ }^{37}$ The Virginia court declared that:

It is reasoning in a circle, to argue that a fraud is made out, when it is shown by oral testimony that the obligee contemporaneously with the execution of a bond, promised not to enforce it. Such a principle would nullify the rule: for conceding that such an agreement is proved, or any other contradicting the written instrument, the party seeking to enforce the written agreement according to its terms, would always be guilty of fraud. ${ }^{38}$

The Pendergrass court repeated this statement, ${ }^{30}$ as had Wigmore. ${ }^{40}$ After alluding to Wigmore's position that an intent not to perform a promise cannot be considered fraud, ${ }^{41}$ it cited several non-fraud cases and decided for the bank. ${ }^{42}$

The court seems to have been mistaken in relying on Towner v. Lucas' $E x^{\prime} r$ to support its conclusion. Wigmore quoted the case to discredit a former Pennsylvania rule that it was fraud to insist on a writing when there had been an earlier oral agreement to the contrary, a rule that is almost universally rejected..$^{43} \mathrm{He}$ did not cite it to support his view that only evidence of factual fraud is exempted from the parol evidence rule, although there was dicta to that effect in the case. ${ }^{44}$ Furthermore, there was no allegation in Towner v. Lucas' Ex'r that the alleged oral promise

\footnotetext{
3554 Va. (13 Gratt.) 705 (1857).

$36 I d$. at 706 .

37 Id. at 722 .

$38 I d$. at 716 .

394 Cal. $2 \mathrm{~d}$ at 263,48 P.2d at $661-62$.

409 WIGMORE, EvTDENCE $\S 2431$ at 104 (3d ed. 1940).

41 Id. § 2439.

424 Cäl. 2d 258, 264, 48 P.2d 659, 662 (1935).

439 WIGMORE, EVIDENCE § 2431 (3d ed. 1940). But cf. International Milling Co. v. Hachmeister, Inc. 380 Pa. 407, 416-17, 110 A.2d 186, 191 (1955); 3 Corbin, Contracts $§ 582$ at 458-59 (1960). See also 3 Corbin, Contracts $\$ 573$, at 57 (Cum. Supp. 1961); Note, 100 U. PA. L. REv. 703 (1952).

44 Towner v. Lucas' Ex'r, 54 Va. (13 Gratt.) 705, 713, 716-17 (1857).
} 
was made without the intention of performing it. The Virginia court merely refused to find that Towner's enforcement of the writing, despite a contrary oral promise, constituted fraud. ${ }^{45}$ To find fraud in these circumstances would have demolished the parol evidence rule. The case certainly is not a holding that evidence of promissory fraud is admissible only if the alleged oral agreement is consistent with the writing.

We have, then, the court establishing a rule contrary to its own precedents, relying on a position of Wigmore that is contrary to the statute law in California, and citing as authority a case that does not deal with the same question. The possible reasons why the supreme court took this step will be explored in detail later in this Article.

\section{California Cases Since Pendergrass}

In Pendergrass the supreme court failed to consider the precise issue before it. Perhaps the court considered only the potential danger to lenders of the opposite result. In any event, it ignored relevant statutes and probably was unaware of its own contrary holding in Langley $v$. Rodriguez. ${ }^{46}$ However, in spite of its dubious quality as a precedent, Pendergrass has displayed remarkable vitality.

Since 1935 there has been the usual plethora of cases recognizing in dicta the so-called fraud exception without suggesting that a different rule obtains for promises allegedly made without intent to perform. ${ }^{47}$ of course, the requirement of consistency has not been applied in the factual misrepresentation cases, ${ }^{48}$ and where the courts have found any factual misrepresentations in addition to the alleged pronises, they have been able to avoid Pendergrass. ${ }^{49}$ This often has been done after paying homage to Pendergrass, with no analysis of whether the real inducement was the false promise or the misrepresentation. ${ }^{50}$

Some cases have displayed a degree of liberality in the determination of what is consistent, ${ }^{51}$ a few have ignored Pendergrass and have relied

$45 I d$, at 724 .

46 See text at notes 20 and 21 supra.

47 Oakland Medical Bldg. Corp. v. Aureguy, 41 Cal. 2d 521, 523, 261 P.2d 249, 250 (1953). See also DeOlazabel v. Mix, 24 Cal. App. 2d 258, 74 P.2d 787 (1937).

48 Richard v. Baker, 141 Cal. App. 2d 857, 297 P.2d 674 (1956) (misrepresentation of property boundary line).

40 Shyvers v. Mitchell, 133 Cal. App. 2d 569, 284 P.2d 826 (1955); see Palm v. Smither, 52 Cal. App. 2d 500, 126 P.2d 428 (1942).

50 Shyvers v. Mitchell, supra note 49.

51 Simmons v. California Institute of Technology, 34 Cal. 2d 264, 209 P.2d 581 (1949); Dillon v. Sumner, 153 Cal. App. 2d 639, 315 P.2d 84 (1957) ; Morris v. Harbor Boat Bldg. Co., 112 Cal. App. 2d 882, 247 P.2d 589 (1952); See Note, 38 CAcr. L. Rev. 535 (1950) (excellent discussion of Simmons v. California Institute of Technology, supra). 
on an alternative ground of ambiguity in the agreement..$^{52}$ One case ${ }^{53}$ distinguished Pendergrass by calling a warranty ${ }^{54}$ a statement of fact. In another, the party alleging fraud was able to convince the district court of appeal that his action for damages sounded in tort and was not an action to enforce the oral promise..$^{55}$ Where there was evidence of fraud in the execution, the Pendergrass rule was not applied. ${ }^{50}$ And although the parol evidence rule is generally recognized as a rule of substantive law, failure to object to the admission of evidence of fraud has been held to preclude raising the question on appeal. ${ }^{57}$ However, despite these methods of avoiding the case, Pendergrass has been followed in a good many instances. ${ }^{58}$

52 Chastian v. Belmont, 43 Cal. 2d 45, 271 P.2d 498 (1954); Willson v. Niagara Duplicator Co., 88 Cal. App. 2d 63, 198 P.2d 362 (1948).

53 Morris v. Harbor Boat Bldg. Co., 112 Cal. App. 2d 882, 247 P.2d 589 (1952), where the alleged warranty was that a cabin cruiser "was capable of, and would attain and maintain, a speed of 36 miles per hour and at that speed had a cruising range of 250 miles." The court rejected the applicability of Pendergrass by stating: "The present case does not involve any oral promise to do anything." $1 d$. at 888,247 P.2d at 593. The court went on to say that this was an addition to the writing, not something inconsistent with it. See also Goldberg v. Underhill, 95 Cal. App. 2d 700, 213 P.2d 516 (1950).

54 See note 17 supra.

55 Cobbledick-Kibbe Glass Co. v. Pugh, 161 Cal. App. 2d 123, 326 P.2d 197 (1958). Here the form contract for the sale of plate glass expressly provided that the seller would not be responsible for condensation or frost on the glass. When the seller sued for the purchase price, the buyer counterclaimed, alleging an oral representation that there would be no condensation. The court rejected an offspring of Pendergrass, Cobbs v. Cobbs, 53 Cal. App. 2d 780, 128 P.2d 373 (1942) by stating:

This is not a case where a promise is made inconsistent with the writing and not contained within it and where the action is on the written promise. The cross-action of respondent asserting fraud is not an action on the contract. It is an action ex delicto which affirms the contract but seeks damages for the fraud that induced its execution. 161 Cal. App. 2d at 126, 326 P.2d at 199.

But see Oxnard Theatres, Inc. v. Paramount Pictures, Inc., 24 F. Supp. 44 (S.D. Cal. 1938); Abbot v. Stevens, 133 Cal. App. 2d 242, 284 P.2d 159 (1955).

56 Fleury v. Ramacciotti, 8 Cal.2d 660, 67 P.2d 339 (1937). See also Cobbledick-Kibbe Glass Co. v. Pugh, 161 Cal. App. 2d 123, 326 P.2d 197 (1958).

57 Pao Ch'en Lee v. Gregoriou, 50 Cal. 2d 502, 326 P.2d 135 (1958); Ferrara v. La Sala, 186 Cal. App. 2d 263, 9 Cal. Rptr. 179 (1960).

58 Bank of America Nat'1 Trust \& Sav. Ass'n v. Lamb Fin. Co., 179 Cal. App. 2d 498, 3 Cal. Rptr. 877 (1960) (oral promise that bank would not sue guarantor of corporate note; note was to the contrary); Newmark v. $H \&$ H Products Mfg. Co., 128 Cal. App. 2d 35, 274 P.2d 702 (1954) (oral warranty of quality of goods; contract stated "as is"); Abbot v. Stevens, $133 \mathrm{Cal}$. App. 2d 242, 284 P.2d 159 (1955) (oral promise that creditor would not require a bonus for prepayment; writing specified the contrary); Cobbs v. Cobbs, $53 \mathrm{Cal}$. App. 2d 780, 128 P.2d 373 (1942) (oral promise by wife that she would cancel separation contract; contract gave her a monthly sum for hife); Shaw v. McCaslin, 50 Cal. App. 2d 467, 123 P.2d 102 (1942) (oral promise not to enforce payment of note); Partanian v. Flodine, $95 \mathrm{Cal}$. App. 2d Supp. 931, 213 P.2d 790 (1950) (oral promise that buyer could cancel; contract expressly not subject to cancellation). Compare Bank of America Nat'1 Trust \& Sav. Ass'n v. Lamb Fin. Co., stipra, with Salzman Sign Co., Inc. v. Beck, 10 N.Y.2d 63, 217 N.Y.S.2d 55, 176 N.E.2d 74 (1961) (corporate officer absolved on Statute of Frauds ground). 


\section{E. Reflections on the Pendergrass Case}

A thoughtful consideration of Pendergrass demands an inquiry into why the integration aspect of the parol evidence rule does not apply to fraud. It is clear that a contract can be attacked if there are formation defects of a serious nature. If consent is not freely given, then no contract is formed, and consent is not freely given if it is induced by fraud. It follows that evidence establishing such a defect cannot be excluded by the parol evidence rule. ${ }^{59}$ The rule presupposes a contract, since it is grounded on the intention of the parties that the writing is to contain their complete agreement. Ignoring for the moment the refinancing aspects of the Pendergrass case, it appears that the debtors were simply trying to get an extension of their demand note. Had they wanted to assert that no contract was validly formed because of the bank's fraud, the court would have been required to restore the status quo. The debtors apparently could not or did not wish to do this. Instead, they were in effect rewriting the note to accord with their version of the contract. In other words, the debtors were using the defect of formation theory to avoid the parol evidence rule, yet were attempting to continue the contract whose very existence they attacked by allegations of fraud. They were trying to obtain the benefits of the contract without the burden of the contractcreated parol evidence rule. ${ }^{60}$ The net result was an attempt to reform the contract in a jury trial.

\section{II}

\section{CASES FROM OTHER JURISDICTIONS}

An evaluation of the Pendergrass case requires that further questions be resolved:

1. Do the courts in other states limit the admissibility of promissory fraud in some manner?

2. Can the apparent inconsistencies in the decisions be explained by differences in the attempted use of the promissory fraud? Do the courts tend to reject evidence of fraud when the party does not claim that the contract is defective, but rather that his oral version of the contract should be enforced?

\section{A. Limitations Placed on the Admissibility of Promissory Fraud}

Some cases allow evidence only of fraud in the execution and will not permit evidence to contradict a writing if fraud in the inducement is

59 McCormick, Evidence 449-51 (1954); see Jones, Evidence in Civil Cases 548 (1912).

60 Compare Yoder v. Nutrena Mills, Inc., 294 F.2d 505, 516 (8th Cir. 1961). See also Creasy Corp. v. Dunning, 183 Wis. 388, 196 N.W. 775 (1924). 
alleged. ${ }^{61}$ These terms are used loosely in the cases, ${ }^{a 2}$ and when fraud in the procurement is thrown in, greater confusion results. ${ }^{63}$ As used in this article, fraud in the execution, or as it is sometimes called, fraud in the integration, ${ }^{64}$ means deception by one party about the contents of the written instrument. This may occur when one party tells the other that a provision to which they have orally agreed is in the writing when it is not, or when one party inserts a provision knowing it was not a part of the oral agreement. The issues here are usually what duties of disclosure are present, whether there was reasonable reliance, and whether one party was too careless in not inspecting the writing. Fraud in the execution does not cover terms consciously omitted from the writing by the parties.

Fraud in the inducement occurs when one party, by means of false statements of fact, warranties, or promises, misleads another into contracting. It does not concern the contents of the writing, but only the antecedent negotiations.

The general rule is that a promise made without the intent to perform it is fraud. ${ }^{65}$ In reaching this conclusion, the courts frequently make use of Lord Bowen's famous remark that "the state of a man's mind is as much of a fact as the state of his digestion." cases do not involve the parol evidence rule, because the false promise is in writing and the defrauded party pursues an alternative remedy in tort, ${ }^{87}$ there is no writing, ${ }^{68}$ or the fraud occurs after the contract is formed. ${ }^{6 \theta}$

81 Steiner Bros. v. Slifkin, 237 Ala. 226, 186 So. 156 (1939); Swayne v. Felici, 84 Conn. 147, 79 Atl. 62 (1911) (by implication); England v. Houser, 178 Mo. App. 70, 163 S.W. 890 (1914). Goldsmith v. Vrooman, 68 Ga. App. 528, 23 S.E.2d 504 (1942) leld that unless there was. fraud in the execution, the innocent party could only rescind, but not sue for damages. But a year later an innocent party was allowed to sue in tort for deceit on the theory that he had returned the car and rescinded the contract. Since he lad rescinded, there was no contract left to which the parol evidence rule could apply. Eastern Motor Co. v. Lavender, $69 \mathrm{Ga}$. App. 48,24 S.E.2d 840 (1943). If he had affirmed and sued for damages, he would probably have lost. Yet the result here is to allow him to rescind and sue for damages, something most courts do not permit.

62 See Langley v. Rodriguez, 122 Cal. 580, 582, 55 Pac. 406, 407 (1898); Councill v. Sun Ins. Office of London, $146 \mathrm{Md}$. 137, 149, 126 Atl. 229, 234 (1924); Franklin Bond Corp. v. Smith, 163 Okla. 70, 20 P.2d 912 (1933).

63 Collins v. Southern Brick Co., 92 Ark. 504, 508, 123 S.W. 652, 653 (1909); Langley v. Rodriguez, supra note 62 .

64 Dawson \& Palmer, Cases on Restitution 708 (1958).

65 Prosser, Torts 564 (2d ed. 1955); Restatement, Contracts $\$ 473$ (1932); RestateMENT, TORTS $\$ 530$ (1938).

66 Edgington v. Fitzmaurise, 29 Ch. D. 459,483 (1885).

67 Knudson v. Domestic Util. Mfg. Co., 264 Fed. 470 (9th Cir. 1920) ; Squire's Dep't Store, Inc. v. Dudum, 115 Cal. App. 2d 320, 252 P.2d 418 (1953); Hobaica v. Byrne, 123 Misc. 107, 205 N.Y.S. 7 (Sup. Ct. 1924). Prosser, Selected Topics on the Law or Torts 400-02 (1953).

68 Berkey v. Halm, 101 Cal. App. 2d 62, 224 P.2d 885 (1950); Herndon v. Durham \& S. Ry. Co., 161 N.C. 650,77 S.E. 683 (1913).

69 Philadelplia Storage Battery Co. v. Kelley-How-Thomson Co., 64 F.2d 834 (1933). 
The issue of admissibility arises when the opponent of the evidence of promissory fraud attempts to invoke the bar of the parol evidence rule. Most of the cases, in accord with the Restatement, ${ }^{70}$ allow evidence of promissory fraud, despite the rule. ${ }^{71}$ As in California, many of the cases that admit such evidence also involve misrepresentations of fact, and the courts ordinarily do not state whether these misrepresentations are sufficient in themselves to establish the fraud. ${ }^{72}$ Some decisions have used a test similar to Pendergrass that requires a comparison of the writing and the oral agreement. ${ }^{73}$ However, a sizeable number of cases exclude the

70 Restatexient, Contracts $\$ 238$ (1932).

7I Globe Steel Abrasive Co. v. National Metal Abrasive Co., 101 F.2d 489 (6th Cir. 1939); Keeler v. Fred T. Ley \& Co., 65 F.2d 499 (1st Cir. 1933), criticized, 28 ILL. L. REv. 717 (1934); Porter v. Reid, 79 F. Supp. 898 (D.C. Mass. 1948) ; Nelson Realty Co. v. Darling Shop of Birmingham, Inc., 267 Ala. 301, 101 So. 2d 78 (1957); Lusk Corp. v. Burgess, 85 Ariz. 90, 332 P.2d 493 (1958); Baker v. Allen, 68 Colo. 59, 189 Pac. 4 (1920); Sallies v. Johnson, 85 Conn. 77, 81 Atl. 974 (1911); Grand Tower \& Cape Girardeau R. v. Walton, 150 Ill. 428, 37 N.E. 920 (1894) ; Councill v. Sun Ins. Office of London, 146 Md. 137, 126 Atl. 229 (1924); Schupp v. Davey Tree Expert Co., 235 Mich. 268, 209 N.W. 85 (1926); Goodwin v. Horne, 60 N.H. 485 (1881) ; Adams v. Gillig, 199 N.Y. 314, 92 N.E. 670 (1910) ; National Cash Register Co. v. Midway City Creamery Co., 49 N.D. 441, 191 N.W. 762 (1922) ; McLean v. Southwestern Cas. Ins. Co. of Okla., 61 Okla. 79, 159 Pac. 660 (1915) ; Claude v. Claude, 180 Ore. 62, 174 P.2d 179 (1946); Rectenbaugh v. Northwestern Port Huron Co., 22 S.D. 410, 118 N.W. 697 (1908); Texas \& P. Ry. v. Presley, 137 Tex. 232, 152 S.W.2d 1105 (1941); Wilbur v. Prior, 67 Vt. 508, 32 Atl. 474 (1895); Nethercutt v. Hopkins, 38 Wash. 577, 80 Pac. 798 (1905). But see Farris v. Strong, 24 Colo. 107, 48 Pac. 963 (1897); Swayne v. Felici, 84 Conn. 147, 77 Atl. 62 (1911); Hoff v. Peninsula Drainage Dist. \#2, 172 Ore. 630, 143 P.2d 471 (1943).

A large number also permit evidence of warranty promises. E.g., Hall v. Crow, 240 Iowa 81, 34 N.W.2d 195 (1948) (statement about yield of hybrid corn considered a statement of fact); New England Foundation Co., Inc. v. Elliott A. Watrous, Inc., 306 Mass. 177, 27 N.E.2d 756 (1940) (statement that machine would be in perfect working condition and it would do a certain amount of work per hour).

72 Northwestern Rug Mfg. Co. v. Leftwich Hardware and Furniture Co., 176 Ark. 212, 2 S.W.2d 1109 (1928); Shipfer v. Stone, 206 Iowa 328, 218 N.W. 568 (1928); Good Roads Mach. Co., Inc. v. Ott, 186 Iowa 908, 171 N.W. 721 (1919); White v. Smith, 79 Kan. 96, 98 Pac. 766 (1908); Ingle Sys. Co. v. Coil, 211 S.W. 904 (St. Louis Ct. of App. 1919); Chapin v. Noll, 118 Neb. 318, 224 N.W. 687 (1929). But see Reed v. Cooke, 331 Mo. 507, 55 S.W.2d 275 (1932).

73 Kelly v. Ellis, 39 Mont. 597, 104 Pac. 873 (1909); Tallman v. First Nat'l Bank of Nevada, 66 Nev. 248, 208 P.2d 302 (1949) (dictum; no allegation of fraud); Winoka Village v. Tate, 16 N.J. Super. 330, 84 A.2d 626 (1951) ; Alford v. Rowell, 44 N. Mex. 392, 103 P.2d 119 (1940). There is language in Beers v. Atlas Assur. Co., 215 Wis. 165, 253 N.W. 584 (1934) and Nelson v. Berkner, 139 Minn. 301, 166 N.W. 347 (1918) that the greater the inconsistency between the oral promise and the writing, the less likely that there was reliance, or that it was reasonable. In Nelson v. Berkner, supra, the court stated that it would be rare that reliance in these cases would be reasonable. However, they went on to hold that it was proper to submit the question of rehance to the jury. In McCreight v. Davey Tree Expert Co., 191 Minn. 489, 254 N.W. 623 (1934), the Minnesota court cited Nelson v. Berkner, but held that the judge should not have admitted the evidence. See also General Corp. v. General Motors Corp., 184 F. Supp. 231 (D.C. Minn. 1960) (collecting Minnesota cases).

Kelly v. Ellis, Alford v. Rowell, and Winoka Village v. Tate, all supra, actually go a step beyond Pendergrass. They will not admit the evidence of fraud if the subject matter of the fraudulent promise is dealt with in the writing. This is the test used in determining the existence of a consistent collateral agreement. 
evidence of promissory fraud, usually on the theory that the parol evidence rule represents a strong public policy. ${ }^{74}$

\section{B. Uses Made of the Evidence of Fraud}

We should first consider what the defrauded person might want to accomplish by proving fraud..$^{75}$ On the milder side of the remedy spectrum, he may simply want to call the deal off. Rescission, though a term of many meanings, will be used here to mean the objective sought by a party who attacks the formation of a contract. Seeking rescission, he claims lis consent was obtained by fraud, and that the status quo ante should be restored. In the typical sales transaction, the defrauded buyer may seek restitution of his money on the theory that the defrauding party has been unjustly enriched. If the buyer is sued for the unpaid portions of the purchase price, he may defend on the ground of fraud offering to restore the status quo.

The innocent party may desire a judicial declaration that no valid contract exists. If he has been fraudulently induced to sell land, he may sue to cancel the contract or deed and clear his title. A defrauded buyer, rather than wait until he is sued, may bring an action to rescind to avoid

74 Holt v. Quaker State Oil Ref. Co., 67 F.2d 170 (4th Cir. 1933) ; Farris v. Strong, 24 Colo. 107, 48 Pac. 963 (1897) ; Swayne v. Felici, 84 Conn. 147, 79 Atl. 62 (1911); Thomson v. McLaughlin, 13 Ga. App. 334, 79 S.E. 182 (1913) (confusing dictum that it might be fraud); Burt v. Bowles, 69 Ind. 1 (1879) ; Loughery v. Central Trust Co., 258 Mass. 172, 154 N.E. 583 (1927); Knowlton v. Keenan, 146 Mass. 86, 155 N.E. 127 (1888); McCreight v. Davey Tree Expert Co., 191 Minn. 489, 254 N.W. 623 (1934); Reed v. Cooke, 331 Mo. 507, 55 S.W.2d 275 (1932); Guthrie \& W. Ry. v. Rhodes, 19 Okla. 21, 91 Pac. 1119 (1907) ; Hoff v. Peninsula Dräinage Dist. \#2, 172 Ore. 630, 143 P.2d 471 (1943); Beers v. Atlas Assur. Co., 215 Wis. 165, 253 N.W. 584 (1934). But see Baker v. Allen, 68 Colo. 59; 189 Pac. 4 (1920); Sallies v. Johnson, 85 Conn. 71, 81 Atl. 974 (1911); Claude v. Claude, 180 Ore. 62, 174 P.2d 179 (1946).

Perhaps one of the reasons Minnesota does not permit the parol evidence is that in Minnesota fraud can be established by a fair preponderance of the evidence. Hafner v. Ritzinger, 256 Minn. 196, 97 N.W.2d 839 (1959).

As is apparent from the existence of conflicting cases in several of the jurisdictions cited, it is frequently difficult to state the law in a given jurisdiction. Many of the cases are decided without reference to earlier conflicting precedents, a phenomenon that is common where the parol evidence rule is involved. See Colorado, Connecticut, and Oregon cases cited above and note 71 supra.

It is often difficult to determine whether a court rejects promissory fraud or whether it merely concludes that there was insufficient evidence of the promise or of the absence of intent to perform it. See Holt v. Quaker State Oil Ref. Co., sicpra, where the court stated that fraud has to consist of a present or past fact misrepresentation, but also held that the evidence did not support the allegation that the promise was made without an intention to perform.

Also, it is not clear from the cases whether the evidence is rejected because the statement was a prediction or a mere statement of intention and not a promise. See Guthrie \& W. Ry. v. Rhodes, supra.

These factors illustrate the lazards of attempting to determine the position of any state in this area of law. The citations given therefore are not intended as a definitive catalog.

75 For a complete discussion of the many choices that may be available see Prosser, Torts 531 (2d ed. 1955). 
losing the remedy of rescission through delay or an election of remedies. He may sue simply to get the dispute settled as soon as possible. Whatever he seeks to accomplish, and regardless of who initiates the action, the theory of the victim of fraud is the same: No contract has been formed.

Rather than calling the deal off and restoring the status quo, the defrauded party may seek a remedy that goes beyond mere rescission. He may desire to get specific performance of the false promise; more likely, he will affirm the contract and sue for damages. Although by the latter remedy he will not get the performance purportedly promised, he may get damages as a substitute in those states that allow him to use the value of the promised performance as the measure of recovery.

Also, by using the doctrine of conditions, a defense based upon the false promise might be asserted. ${ }^{\text {TB }}$ Performance of the oral promise would be claimed as a condition precedent to any performance by the promisee. For instance, a tenant sued for non-payment of rent might claim as a defense an unperformed oral promise by the landlord. If the promise seems contradictory to the written lease, the tenant might contend the promise was made with no intent to perform it, asserting promissory fraud as his defense. In effect, the tenant maintains that his promise to pay rent is conditioned upon the performance of the landlord's oral promise. ${ }^{77}$ As in Pendergrass, this amounts to a reformation of the contract. It is a method of enforcing the oral promise, just as are actions for specific performance or damages. From this it should be apparent that expressions such as "a shield but not a sword" are of no assistance in determining the possible tactics of a defrauded person. As a plaintiff, he may wish to deny the contract and rescind; as a defendant, he may wish to defend by seeking enforcement of the false promise. The only useful analytical differentiation is between enforcement and non-enforcement of the promise.

The cases that permit evidence of promissory fraud despite a writing are in the main suits for rescission, frequently coupled with a demand for restitution. ${ }^{78}$ There are quite a few cases that allow an action for damages sounding in tort, frequently with the measure of recovery based upon the

78 See Dillon v. Sumner, 153 Cal. App. 2d 639, 315 P.2d 84 (1957). Here the defense was based upon the payee's promise being a consistent collateral agreement while the counterclaim was based upon fraud.

77 Compare Swayne v. Felici, 84 Conn. 147, 79 Atl. 62 (1911) (imvolving fraud in the execution).

78 See, e.g., Hansen v. Danicl Hayes Co., 152 Minn. 222, 188 N.W. 317 (1922); Johnson v. Nebraska Bldg. \& Inv. Co., 109 Neb. 235, 190 N.W. 590 (1922) ; National Cash Register Co. v. Midway City Creamery Co., 49 N.D. 441, 191 N.W. 762 (1922); National Cash Register Co. v. Mahaney, 49 S.D. 1, 205 N.W. 710 (1925); Jack W. Neal Auto Co. v. Serna, 259 S.W. 999 (Tex. Civ. App. 1924). 
contract. ${ }^{79}$ Some jurisdictions that place limits on promissory fraud deny a tort remedy on the theory that since the promise could not be enforced because of the parol evidence rule, the law should not allow a party to do indirectly what he could not do directly. ${ }^{80}$ The Restatement of Torts, however, takes a contrary position. ${ }^{81}$ Evidence of fraud is sometimes allowed when the effect is to reform the contract; the contract continues in force on the terms of the innocent party. ${ }^{82}$ And in one instance, a court ordered specific performance of the false promise. ${ }^{83}$

The cases from other jurisdictions, and Califorma cases after Pendergrass, ${ }^{84}$ show that the parol evidence, once admitted, can be used in a variety of ways. A number of the cases allow the defrauded party to go beyond calling the deal off and restoring the status quo. In effect, the false promise is being enforced, directly or indirectly. It seems, therefore, that

70 Keeler v. Fred T. Ley \& Co., 65 F.2d 499 (1st Cir. 1933) (New York law); Dillon v. Sumner, 153 Cal. App. 2d 639, 315 P.2d 84 (1957); Berning v. Colodny \& Colodny, 103 Cal. App. 188, 284 Pac. 496 (1930); Eastern Motor Co. v. Lavender, 69 Ga. App. 48, 24 S.E.2d 840 (1943) ; Coleman v. Ammons, 249 S.W.2d 1014 (Tex. Civ. App. 1952), 31 Texas L. Rev. 906; New England Foundation Co., Inc. v. Elliott A. Watrous, Inc., 306 Mass. 177, 27 N.E.2d 756 (1940); Berrendo Irrigated Farms Co. v. Jacobs, 23 N.M. 290, 168 Pac. 483 (1917); White v. Fisheries Prod. Co., 185 N.C. 68, 116 S.E. 169 (1923); Lone Star Olds Cadillac Co. v. Vinson, 168 S.W.2d 673 (Tex. Civ. App. 1943).

80 Abbot v. Stevens, 133 Cal. App. 2d 242, 284 P.2d 159 (1955) (citing Pendergrass iu an action for damages); Hoff v. Peninsula Drainage Dist. \#2, 172 Ore. 630, 143 P.2d 471 (1943); Beers v. Atlas Assur. Co., 215 Wis. 165, 253 N.W. 584 (1934). But see Cobbledick-Kibbe Glass Co. v. Pugh, 161 Cal. App. 2d 123, 326 P.2d 197 (1958) (allowing tort action) discussed supra note 55 .

81 Restatement, ToRts $\S 530$ (1938). A number of cases loold that an action in tort is permissible where an action for breach of warranty would not lie. Tabor v. Peters, 74 Ala. 90 (1883) ; Hanger v. Evins \& Shinn, 38 Ark. 334 (1881); Parlin v. Sinall, 68 Mc. 289 (1878).

82 Stanard Tilton Milling Co. v. Mixon, 243 Ala. 309, 9 So. 2d 911 (1942); Good Roads Mach. Co., Inc. v. Ott, 186 Iowa 908, 171 N.W. 721 (1919) ; Palmetto Bank \& Trust Co. v. Grimsley, 134 S.C. 493 , 133 S.E. 437 (1926).

In Stanard Tilton Milling Co. v. Mixon, supra, the seller brought an action for breach and buyer crossclaimed asking for rescission. He claimed the seller represented that he could terminate the contract at his pleasure and was not bound to order anything. This was directly contrary to the terms of the contract. The court allowed the evidence and granted rescission. Yet the buyer was allowed to keep the goods slipped at the contract price, so in effect his version of the contract was being enforced.

83 Nelson Realty Co., Inc. v. Darling Shop of Birminghain, Inc., 267 Ala. 301, 101 So. 2d 78 (1957). Contra, Dowd v. Lake Sites, Inc., 365 Mo. 83, 276 S.W.2d 108 (1955).

84 Sinmons v. Califorma Institute of Technology, 34 Cal.2d 264, 209 P.2d 581 (1949) (partial rescission on severability theory, which amounted to enforcenent); Cobbledick-Kibbe Glass Co.v. Pugh, 161 Cal. App. 2d 123, 326 P.2d 197 (1958) (tort action for damages); Dillon v. Sumner, $153 \mathrm{Cal}$. App. 2d 639, 315 P.2d 84 (1957) (action for damages and perhaps defense by doctrine of conditions); Shyvers v. Mitchell, 133 Cal. App.2d 569, 284 P.2d 826 (1955) (defense by surety on note amounting to rescission); Morris v. Harbor Boat Bldg Co., 112 Cal. App. 2d 882, 247 P.2d 589 (1952) (action for damages); Palm v. Smither, 52 Cal. App. 2d 500,126 P.2d 428 (1942) (cancellation of lease and action to quiet title). 
the result in the Pendergrass case can be partially explained by the use the debtors were attempting to make of the parol evidence.

Clearly, the chances that the evidence of fraud will be admitted are much greater when the remedy sought is consistent with the theory that no contract was validly formed. Yet the divergent holdings cannot be rationalized by simply distinguishing between enforcement and nonenforcement of the oral promise. Innocent parties have been able to attack the writing with evidence of fraud and still get a kind of reformation of the writing or damages measured by the oral promise.

\section{III}

\section{ANALYSIS}

Perhaps the conclusion reached in Pendergrass can be explained by the court's fear, engendered by the depression, that a contrary lolding would enable debtors to evade their obligations. Nevertheless, analysis of the rule enunciated requires that two additional questions be considered.

1. What should be the tests for admissibility of promissory fraud when there has been a subsequent written agreement?

2. Are there meaningful advantages to focusing greater attention upon fraud rather than considering it a method by which the effect of the parol evidence rule may be avoided?

In discussing these questions, it will be helpful to have in mind some common transactions $\mathrm{m}$ which the parties reach an oral understanding directly at variance with the writing.

1. Owner and builder orally agree that the building will cost $\$ 100,000$, but sign a written contract that specifies a price of $\$ 125,000$, so that the owner can get a larger building loan.

2. A bank official tells an individual that she will never be asked to pay a guaranty she is about to sign, but that it is needed to satisfy the bank examiners. ${ }^{85}$

3. An insurance adjuster asks an accident victim to $\operatorname{sign}$ a release obligating the insurance company to pay her $\$ 500$, but orally promises that she will receive $\$ 5,000$. The stated purpose is to prevent other injured persons from learning the amount of the settlement.

4. A bank official tells a corporate officer that no personal liability will result from a loan to the corporation, even though the loan indenture states the contrary. The reason given is a reluctance to retype the contract or to use a different form. ${ }^{86}$

85 Shyvers v. Mitchell, 133 Cal. App. 2d 569, 284 P.2d 826 (1955).

${ }^{86}$ Two cases that could be combined to get this example are Bank of America Nat' Trust \& Sav. Ass'n v. Lamb Fin. Co., Inc., 179 Cal. App. 2d 498, 3 Cal. Rptr. 877 (1960) and International Milling Co. v. Hachmeister, Inc., $380 \mathrm{~Pa} .407,110 \mathrm{~A} .2 \mathrm{~d} 186$ (1955). 
5. A new salesman is hired under a written contract that he will receive a commission of five per cent, but with an oral understanding that he will get six per cent, ostensibly to prevent other salesmen from learning that he is receiving a larger commission. ${ }^{87}$

\section{A. Should Fraud in the Execution Be Required?}

A rule that only evidence of fraud in the execution is admissible to contradict a written contract obviously is not affected by the presence of false promises or false representations of fact. But since such a limitation occasionally appears in promissory fraud cases, it merits brief mention.

Apparently, the only basis for distinguishing between fraud in the execution and fraud im the inducement, other than because of historical development, ${ }^{88}$ is to limit assaults on written agreements. However, this desire to protect the written manifestation of the parties' consent should not prevent a party from even attempting to show that there was in fact no consent. The bulk of the fraud cases involve fraud in the inducement, and this form of deception is perhaps the more easily perpetrated. The deluded person should not be barred simply because the defect that he asserts is on the wrong side of a superficial distinction between inducement and execution. A rule permitting relief only from fraud in the execution is rationally unjustifiable.

\section{B. Should It Make Any Difference If the Fraud Is Promissory?}

A number of arguments are made to justify treating fraud based on misrepresentations of fact differently from promissory fraud. Some commentators feel that juries might transform every broken promise into a false promise. ${ }^{89}$ Others contend that juries would interpret statements of intention and prediction as promises, without recogmizing that such statements usually are not relied upon. Critics who would exclude evidence of promissory fraud argue that the matters to be proved-the making of the promise, the absence of intent to perform it, reasonable rehance-usually are extremely difficult to establish. ${ }^{90}$ In their view, the defrauded party could, and therefore should, have protected himself by getting the alleged promise in writing.

It is sometimes asserted that facts lie outside the writing, and promises

87 See Rock-Ola Mfg. Corp. v. Wertz, 282 F.2d 208 (4th Cir. 1960); Nelson v. Frawley, 186 F. Supp. 66 (S.D.N.Y. 1960).

88 Specialty contracts could not be attacked in common-law courts for fraud in the inducement, only fraud in the execution. Ames, Specially Contracts and Equilable Defenses, 9 HARV. L. REv. 49, 51 (1895). Other examples of different treatment of the two types of fraud are found in Dawson \& Patmer, Cases on Restitution 118-19 (1958).

89 Note, 17 N.C.L. REv. 32 (1939).

80 Note, 28 IrL. L. REv. 717 (1934). 
he within it. ${ }^{91}$ This might mean that parties usually intend to integrate only promises, but implicit in the statement is the belief that if promises are made, they will be included in the writing.

Fimally, one of the biggest liurdles to admitting evidence of promissory fraud where a writing is involved is that it seems to enforce a promise in flagrant circumventoin of the parol evidence rule.

Taken in their totality, these arguments are not persuasive. Merely because recognition of a substantive right may require subtle fact shadings should not prevent a litigant from slowing he lias been victimized. Questions of intent and reasonable reliance are constantly before courts. The cases do not indicate that courts or juries have been either unwilling or unable to distinguish statements of intention from promises; ${ }^{22}$ nor have they failed to see the difference between a broken promise and a false one. ${ }^{93}$

With respect to difficulties of proof, the differentiation between representations of facts, warranties, and promises can be very troublesome. ${ }^{94}$ This is evidenced by the cases that classify a promise made without intent to perform as a representation of fact about the state of mind of the promisor. Similarly, a warranty can be interpreted as a representation of fact that a chattel has certain qualities of performance, or has in

91 This seems to be the basis of Wigmore's objection. 9 WIGMORE, EvIDENCE $₹ 2439$ (3d ed. 1940).

92 Porter v. Reid, 79 F. Supp. 898 (D.C. Mass. 1948); Rome v. New River Lodge No. 402, 197 So. 174 (La. App. 1940) ; Bushnell v. Elkins, 34 Wyo. 495, 245 Pac. 304 (1926). See generally Keeton, Fraud-Statements of Intention, 15 TExas L. REv. 185 (1936).

93 See Church of the Merciful Saviour v. Volunteers of America, Inc., 184 Cal. App.2d 851, 8 Cal. Rptr. 48 (1960) ; Locomobile Co. of America v. Belasco, 32 Cal. App. 329, 162 Pac. 920 (1916); Partanian v. Flodine, 95 Cal. App. 2d Supp. 931, 213 P.2d 790 (Super. Ct. App.Div. 1950); Claude v. Claude, 180 Ore. 62, 174 P.2d 179 (1946). See generally Keeton, Fraud: The Necessity for an Intent to Deceive, 5 U.C.L.A.L. REv. 583 (1958).

In the criminal law where the penalties are far greater, the Supreme Court of Cahifornia is willing to differentiate between false and broken promises. In People v. Ashley, 42 Cal.2d 246, 263, 267 P.2d 271, 282, cert. denied, 348 U.S. 900 (1954), noted 43 CaLIF. L. REv. 719 (1955), Justice Traynor stated:

The problem of proving intent when the false pretense is a false promise is no more difficult than when the false pretense is a misrepresentation of existing fact, and the intent not to perform a promise is regularly proved in civil actions for deceit. Specific intent is also an essential element of many crimes. Moreover, in cases of obtaining property by false pretenses, it must be proved that any misrepresentations of fact alleged by the People were made knowingly and with intent to deceive. If such misrepresentations are made innocently or inadvertently, they can no more form the basis for a prosecution for obtaining property by false pretenses than can an innocent breach of contract. Whether the pretense is a false promise or a misrepresentation of fact, the defendant's intent must be proved in both instances by something more than mere proof of nonperformance or actual falsity (cf. United States v. Ballard, 322 U.S. 78 [64 S.Ct. 882, 88 L.Ed. 1148]), and the defendant is entitled to have the jury instructed to that effect.

94 See Hawthorne v. Farrell, 193 A.C.A. 578, 14 Cal. Rptr. 423 (1961); Rectenbaugh v. Northwestern Port Huron Co., 22 S.D. 410, 118 N.W. 697 (1908). 
fact already performed in a particular fashion. It does not take much manipulation to classify a promise as either a warranty or a fact.

The argument that a party can protect himself by insisting on written promises shows a remarkable lack of awareness of the facts of everyday commercial life. It should be apparent that inequality of bargaining power and the standardized form contract are the rule today, rather than the exception. Promises made without the intention on the part of the promisor that they will be performed are unfortunately a facile and effective means of deception.

\section{Should the Promise Be Allowed Only If It Is Consistent With the Writing?}

The flat exclusion of evidence of promissory fraud may be replaced by a rule that permits proof of the oral promise if it is not inconsistent with the writing. This is an improvement. However, this variation adds to the fact-warranty-promise differentiation the determination of what is consistent. A reading of the California cases shows that any attempt to forecast results in this area is a hazardous undertaking.

In Dillon v. Sumner, ${ }^{95}$ the writing dealt with the sale of medical equipment and personal property by one doctor to another. When the seller sued on a note given in part payment, the buyer counterclaimed for damages, alleging fraudulent oral promises by the seller, (1) to transfer the seller's medical practice, and (2) to retire from practice. The court held that the first promise was inconsistent with the writing, so that evidence of it was barred by the parol evidence rule. The second promise was held to be consistent, or in the language of Pendergrass, "not directly at variance," ${ }^{96}$ so that evidence of it was admissible. Another case involved a written promise to pay royalties to the California Institute of Technology ${ }^{97}$ The donor alleged that an oral promise to use the money in certain types of research was falsely made. Here also, the court held the promise consistent with the writing and admitted the evidence.

Of course, where the oral promise is consistent with the writing, the consistent collateral contract doctrine may be asserted. ${ }^{98}$ Without the allegation of fraud, the difficult problem of proving an intent not to perform is thus avoided.

The California rule is a compromise, allowing evidence of false promises only if the alleged promises are consistent with the written contract. Vague distinctions between facts and promises, the finding of false repre-

95153 Cal. App. 2d 639, 315 P.2d 84 (1957).

96 See text at note 9 supra.

97 Simmons v. California Institute of Technology, 34 Cal. 2d 264, 209 P.2d 581 (1949).

98 Stockburger v. Dolan, 14 Cal. 2d 313, 94 P.2d 33 (1939); Greathouse v. Daleno, 57 Cal. App. 187, 206 Pac. 1019 (1922). See 3 Corbin, Contracts $\$ 594$ (1960). 
sentation of fact in addition to the promise, and the flexibility of the consistency test, all provide a court with sufficient working room to do justice in a given case. However, the flat rule laid down by Pendergrass is often followed mechanically and is likely to discourage attorneys from attempting to introduce evidence of fraudulent promises. ${ }^{99}$ The California approach is obviously better than a rule that excludes all evidence of false promises. However, it fails to recognize that application of the parol evidence rule depends on the existence of a validly formed contract. The result is an extension of the rule beyond its logical scope.

\section{Should the Rule Be Based on the Relief Sought?}

Georgia allows evidence of promissory fraud only if the relief sought is rescission and restoration of the status quo. ${ }^{100}$ There is a certain logical attractiveness to this limitation. It fits neatly with the analysis that admits the evidence because it shows a defect of formation affecting the existence of the contract. It avoids the seemingly unfair result of allowing the innocent party to circumvent the parol evidence rule by proving the nonexistence of a contract, and then permitting him to use the contract in some manner. And it also seems to effect a reasonable compromise of the conflict between the policy protecting written agreements and the policy discouraging deception.

There are persuasive analogies for such an approach. Rescission and restoration of the status quo has been a favored remedy. In rescissionrestitution suits in equity, scienter was not required, ${ }^{101}$ nor was pecuniary harm necessary. ${ }^{102}$ And where a principal manifests that his agent is not employed to make representations, many states will allow a third party to rescind if he is subsequently misled by the agent, but will not allow actions for damages against the principal. ${ }^{103}$

The Georgia limitation has not been used often. Instead, many courts mechanically repeat that a defrauded person has an election of remedies; $;^{104}$ he may rescind, or affirm the contract and sue for damages. There are, however, more cogent reasons for rejecting this solution as a remedial compromise.

89 In Travelworld Inc. v. Margolin, 168 Cal. App. 2d 744, 336 P.2d 587 (1959), the trial court ruled out any attempt to introduce parol evidence, relying upon Pendergrass. No appeal was taken from this ruling.

100 Goldsmith v. Vrooman, 68 Ga. App. 528, 23 S.E.2d 504 (1932). But see Eastern Motor

Co. v. Lavender, 69 Ga. App. 48, 24 S.E.2d 840 (1943).

101 Prosser, TORTS 525 (2d ed. 1955).

102 Id. at 567 .

103 Speck v. Wylie, 1 Cal. $2 \mathrm{~d}$ 625, 36 P.2d 618 (1934); Restatencent (Second), Agency $\S 260$ (1958); see Comment, 27 Texas L. REv. 361, 370 (1949).

104 Dallas Farm Mach. Co. v. Reaves, 158 Tex. 1, 307 S.W.2d 233 (1957); Coleman v. Ammons, 249 S.W.2d 1014 (Tex. Civ. App. 1952), 31 Texas L. Rev. 906 (1953). 
Of primary importance is the weakening of the policy that supports the parol evidence rule and the concurrent growth of the policy against fraud. Influenced by Wigmore and Corbin, many courts now recognize that the parol evidence rule relates most sigmificantly to the integration of agreements imto one final writing. Although it is still used as a kind of "best evidence" standard, there is no doubt that the many exceptions and limitations to its application reflect serious dissatisfaction with the rule.

For instance, if the integration test is stressed, the alleged oral promise may be admitted, without allegations of fraud, on the consistent collateral contract theory, or the theory of partial integration. ${ }^{105}$ If Wigmore's position on the abolition of the plain meaning rule is followed, either overtly or covertly, it may be possible to show by interpretation that a term in the writing was intended to mean the opposite of its apparent meaning. ${ }^{100}$ It may be possible to show that the writing is a sham. ${ }^{107}$ If the alleged oral promise can be classified as a condition, the effect of the writing may be avoided. ${ }^{108}$ Finally, the vague exception based on the "true nature of the consideration" may be utilized to avoid the rule. ${ }^{109}$ Obviously, the potency of the rule has been diluted so that it no longer represents the strong legal policy that it once did.

On the other hand, some of the obstacles to establishing fraud are being relaxed. Carelessness of the innocent party is less likely to be a bar, ${ }^{110}$ the requirement of scienter is weakening, ${ }^{111}$ and the pecuniary dam-

1053 Corbin, Contracts $\$ \$ 581,582,588,594$ (1960). See Spurgeon v. Buchter, 192 A.C.A. 214, 13 Cal. Rptr. 354 (1961) ; Post v. Palpar, Inc., 184 Cal. App. 2d 676, 7 Cal. Rptr. 823 (1960).

1089 Wigmore, Evidence $\$ 2463$ (3d ed. 1940); 3 Corbin, Contracts $\$ 544$ (1960). A number of California cases that still claim to use the plain meaning rule have gone quite far in obliterating it. Reid v. Overland Mach. Prod., 55 Cal. 2d 203, 359 P.2d 251, 10 Cal. Rptr. 819 (1961); Wachs v. Wachs, 11 Cal. 2d 322, 79 P.2d 1085 (1938). See McBaine, The Rule Against Disturbing Plain Meaning of Writings, 31 CALrF. L. REv. 145 (1943). See also Posner v. Grunwald-Marx, Inc., 56 A.C. 159, 363 P.2d 313, 14 Cal. Rptr. 297 (1961) (collective bargaining arbitration).

107 P. A. Smith Co. v. Muller, 201 Cal. 219, 256 Pac. 411 (1927); 3 Corbin, Contracts $\S 577$ (1960); Tracy, Admissibility of Parol Evidence Showing That Contract in Writing Was Executed Only as Sham, 33 MicH. L. REv. 410 (1935). Yet in cases where in essence the defense to an action on a note is that it was never intended as a note, Califoruia has felt constrained to follow Pendergrass unless some method of avoiding it can be found. Shyvers v. Mitchell, 133 Cal. App. 2d 569, 284 P.2d 826 (1955). Cf. Texas Co. v. Berry Garage, 121 Cal. App. 455, 9 P.2d 241 (1932), which employed sham to enforce an oral promise despite a contrary writing.

108 Doria v. International Umion, Allied Indust. Workers of America, 196 A.C.A. 21, $16 \mathrm{Cal}$. Rptr. 429 (1961); Campbell v. Taylor, 189 A.C.A. 253, 11 Cal. Rptr. 271 (1961); Whiteman v. Leonard Realty Co., 189 A.C.A. 401, 11 Cal. Rptr. 211 (1961); 3 Corans, Contracts \& 589 (1960).

1093 Corbin, Contracts § 586 (1960).

110 Seeger v. Odell, 18 Cal. 2d 409, 115 P.2d 977 (1941). See Prosser, Torts 552 (2d ed. 1955).

111 Prosser, Torts 537-41 (2d ed. 1955); Dawson \& PaLmer, Cases on Restitution 292 (1958). 
age rule is slowly losing its effect. ${ }^{112}$ The scope of justifiable reliance is broadening, ${ }^{113}$ and greater duties of disclosure are being imposed. ${ }^{114}$ These developments show that courts are taking a more active role in policing shady commercial transactions and protecting innocent, gullible parties in the commercial world. ${ }^{115}$ The efforts of the courts have been matched by legislatures.

There are other reasons why limiting the remedy to rescission and restoration of the status quo is not desirable. First, the remedy may be inadequate. Restoration of the status quo may be practically impossible, ${ }^{116}$ especially after the lapse of a long period of time ${ }^{117}$ and the intervention of third-party rights. ${ }^{118}$ Rescission still has pitfalls, such as the necessity for prompt notice and the unfortunate remnants of the doctrine of election of remedies. ${ }^{119}$ Furthermore, Dean Keeton suggests that since the objective of both restitution and damages is to restore the status quo, either remedy ought to be permitted. ${ }^{120}$

In addition, this remedy may not be capable of adequately policing deceptive conduct. If the only penalty is restoration of the status quo,

112 Earl v. Saks \& Co., 36 Cal. 2d 602, 226 P.2d 340 (1951). See Prosser, Torts 566-68

(2d ed. 1955); Note, 39 CarTr. L. REv. 309 (1951).

113 Prosser, TORTs 552-53, 561 (2d ed. 1955).

114 Koch v. Williams, 193 A.C.A. 585, 14 Cal. Rptr. 429 (1961); Barder v. McClung, 93 Cal. App. 2d 692, 209 P.2d 808 (1949); Clauser v. Taylor, 44 Cal. App. 2d 453, 112 P.2d 661 (1941). See also Keeton, Fraud-Concealment and Non-disclosure, 15 TEXAs L. REv. 1 (1936) ; Keeton, Rights of Disappointed Purchasers, 32 TExas L. REv. 1, 16 (1953).

It is interesting to note that inany of the very forward-looking cases in the fraud area are California cases. This is in marked contrast to the retrograde treatinent of the relationship of promissory fraud to the parol evidence rule engendered by Pendergrass.

115 For two recent California examples see Hawthorne v. Farrell, 193 A.C.A. 578, 14 Cal. Rptr. 423 (1961) and Koch v. Willianıs, 193 A.C.A. 585, 14 Cal. Rptr. 429 (1961).

110 See Anerican Historical Soc'y, Inc. v. Storer, 232 Mass. 372, 122 N.E. 392 (1919); Haggen v. Landeis, 56 Wash. 2d 289, 352 P.2d 636 (1960).

117 See Cobbs v. Cobbs, 53 Cal. App. 2d 780, 128 P.2d 373 (1942) (17 years).

118 Bedell Eng'r Co. v. Rouse, 57 Cal. App. 2d 734, 135 P.2d 404 (1943); Coleman v. Auninons, 249 S.W.2d 1014 (Tex. Civ. App. 1952), 31 Texas L. Rev. $906^{\circ}$ (1953); Lone Star Olds Cadillac Co. v. Vinson, 168 S.W.2d 673, 676 (Tex. Civ. App. 1943).

119 Recent amendments to the Cahifornia statutes dealing with rescission have modified some of these requirements. Section 1691 of the Civil Code now allows the service of a pleading starting a rescission action to be considered as notice of rescission. Another change was made by $\S 1693$, which states:

A party who has received benefits by reason of a contract that is subject to rescission and who in an action or proceeding seeks relief based upon rescission shall not be denied relief because of a delay in restoring or in tendering restoration of such benefits before judgment uniess such delay has been substantially prejudicial to the other party; but the court may make a tender of restoration a condition of its judgment.

Section 1692 allows a clain for damage with a claim for rescission and also permits a court to award damages if the court finds the contract has not been rescinded.

120 Keeton, Fraud-Statements of Intention, 15 TexAS L. REv. 185, 218-19 (1936). 
much may be gained by the deceiver with little risk. ${ }^{121}$ The efforts of trade associations and law enforcement agencies to eliminate this type of activity are relatively ineffectual. Punitive damages may help in suppressing fraud, but they are usually unavailable against the principal of a tortfeasor, ${ }^{122}$ and some states require actual damage. ${ }^{123}$

Despite the logical attractiveness of such a limitation, proof of promissory fraud should not be restricted to situations where the remedy sought is rescission and restoration of the status quo. Such a restriction clearly would hamper the effectiveness of efforts to minimize fraudulent dealings.

E. When Promissory Fraud Is Established, Should Any Limits Be Placed Upon the Remedy? Should the Fraudulent Promise Be Enforced, If Necessary?

In many instances the courts have allowed the victim of a false promise to either sue for damages in a tort action of deceit, or affirm the contract and sue for its breach. ${ }^{124}$ If it could be said that an action for damages does not amount to enforcement of the false promise, limiting the remedies to rescission or damages would fit neatly into the defect of formation rationale. Such an approach might be realistic where damages for fraud are based on out-of-pocket loss. But in most jurisdictions, damages are based on what the defrauded party would have received had the promise been performed, and in such cases it is difficult to argue that the promise is not being enforced. ${ }^{125}$ Moreover, the contract comes into play even in out-of-pocket jurisdictions, on occasion. ${ }^{126}$ Of course, it can be argued that the "voidable" contract is merely being used as a measuring rod, but this is unconvincing. ${ }^{127}$ Clearly, the duty of the deceiver is being measured by his words.

Although this may be described as enforcing a false promise, the defrauded party should not be limited to non-enforcement remedies. $\mathrm{He}$

121 In Ward v. Taggart, 51 Cal. 2d 736, 336 P.2d 534 (1959) the court used a combination of the constructive trust and a waiver of tort theory to curb sharp dealing by a real estate agent where the plaintiff was not out-of-pocket as the result of the fraud. The case was noted in 48 CaIIE. L. Rev. 342 (1960); 57 Mich. L. Rev. 1249 (1959); 12 Stan. L. Rev. 270 (1959); 7 U.C.L.A.L. REv. 147 (1960); 13 VAND. L. Rev. 390 (1959).

122 MCCormtck, Dasaages 293 (1935).

123 Id. at 282 (1935); see Note, 70 YALE L.J. 1296 (1961).

124 See note 79 supra.

125 Prosser, Torts 569 (2d ed. 1955); 1 Harper \& JaMres, Torts $\$ 7.15$ (1956); McCorMTCK, DAMLAGES 448 (1935).

128 Ibid.

127 If a court holds a contract is illegal, it may refuse to enforce the contract and leave the parties where they are. It is clear in this context that awarding damages would be enforcing the contract and would not be permitted if the parties are in pari delicto.

The same situation arises where a contract comes within the Statute of Frauds and there is not a sufficient memorandum. Clearly, to award damages rather than order restitution would be enforcing the contract and would not be permitted. 
should be permitted to affirm the contract and sue for its breach, or rescind and recover consequential damages. ${ }^{128}$ More flexible handling of fraud problems would be possible, and more effective policing would result, especially if the loss-of-bargain theory were applied.

The next question is whether the defrauded party should be limited to the remedies already mentioned. In some situations the most reasonable and effective remedy would seem to be specific performance of the false promise.

For instance, in Dillon v. Sumner, ${ }^{129}$ the plaintiff, by written contract, sold his medical equipment to Sumner, and took in part payment a promissory note. When Dillon later sued on the note, Sumner counterclaimed for damages, alleging that Dillon had failed to perform oral promises to transfer his medical practice and to retire, and that these promises were made without any intention of performing them. In other words, Sumner was defending on the ground that any obligation of his to pay the note was excused by Dillon's failure to perform his oral promises. And in addition, he was seeking damages for his failure of performance.

What Sumner expected to show as damages we do not know, but it is apparent that their determination would be extremely difficult. Since California uses the out-of-pocket rule, he would have to prove that what he received was worth less than what he paid. It could be that he had suffered no loss. In a jurisdiction using the loss-of-bargain rule, the determination would be even more difficult. How would he establish the value of the promise not to compete? This seems to be a typical situation where equity would enforce the obhigation of the seller. ${ }^{130}$

If the defrauded party may obtain indirect enforcement of the false promise by way of damages, there is seemingly no good reason to deny indirect enforcement by a defense based upon the doctrine of conditions or direct enforcement by specific performance when the situation requires. ${ }^{131}$ Of course, he would have to meet the traditional requirements for specific performance. ${ }^{132}$ But the equitable remedy should not be denied solely be-

128 While this is somewhat unorthodox in terms of the supposedly inconsistent remedies involved, recent statutory changes are moving in this direction. See CaL. Crv. Code $§ 1692$ (permits rescission and damages). See also Lobdell v. Miller, 114 Cal. App. 2d 328, 250 P.2d 357 (1952); UNIFORar CommarctaI CODE §§ 1-106, 2-608, 2-703, 2-712. The Comment to \$ 2-703 states: "This article rejects any doctrine of election of remedy as a fundamental policy and thus the remedies are essentially cumulative in nature and include all of the available remedies for breach. Whether the pursuit of one remedy bars another depends entirely on the facts of the individual case."

129153 Cal. App. 2d 639, 315 P.2d 84 (1957).

1304 PoMreroy, Equity JURISPRUdence $\$ 1344$ (5th ed. 1941).

131 See UNIForar Comaserciat CoDE \$§ 2-716, 2-721, which seem to give the defrauded buyer a right to specific performance where the goods are umique or in other proper circumstances.

1324 POMERoy, Equity JURISPRUdence $\$ \$ 1400-10$ (5th ed. 1941). 
cause of a supposed bar to enforcement of promises imposed by the parol evidence rule.

Obviously; in enforcing the oral promise, either indirectly or directly, the courts must consider all aspects of the transaction. The parties may have attempted to mislead third parties or the public by not including thei. true agreement in the writing. ${ }^{133}$ In such cases, the courts have sufficient tools available in both law $^{134}$ and equity ${ }^{135}$ to prevent the plan from succeeding.

If reformation were available to the victim of fraud, the need for expanding the other remedies would be materially lessened. Reformation is usually allowed only where there has been a mutual mistake or fraud in the integration of the agreement. ${ }^{136}$ However, a recent New York case ${ }^{137}$ allowed reformation where a term of the contract was consciously omitted, one party relying on a false promise by the other. The court apparently felt the parol evidence rule and the Statute of Frauds prevented enforcement in any other way. Some commentators criticized the case as a misapplication of the law of reformation, ${ }^{138}$ and they seem to have accurately reflected the position of most jurisdictions. ${ }^{139}$

The Statute of Frauds might present an obstacle to reformation, if the promise desired to be included is one that the law requires to be in writing.

133 See examples, Part III supra.

1346 Corbin, Contracts $\$ 1455$ (1951).

1352 POMEROX, EqUTTY JURISPRUDENCE $\S 403$ (5th ed. 1941).

136 Restatement, Contracts $\$ 491$ (1932).

137 Brandwein v. Provident Mut. Iife Ins. Co., 3 N.Y.2d 491, 168 N.Y.S.2d 964, 146 N.E.2d 693 (1957).

138 Note, 58 Colum. L. Rev. 752 (1958). See also, 24 Brookrux L. Rev. 355 (1958);

44 CoRN. L.Q. 124 (1958); 27 Ford L. Rev. 125 (1958); 9 Syracuse L. Rev. 336 (1958).

139 See CaI. Crv. Code § 3399:

When, through fraud or a mutual mistake of the parties, or a mistake of one party, which the other at the time knew or suspected, a written contract does not truly express the intention of the parties, it may be revised on the application of the party aggrieved, so as to express that intention ....

This statute seems to be broad enough to include situations beyond fraud or mistake in integration.

Most of the California cases involve a mutual mistake such as a scrivener's error. Where the basis is fraud, there are many dicta stating that there must be fraud in the integration. E.g., Alameda County Title Ins. Co. v. Panella, 218 Cal. 510, 24 P.2d 163 (1933). However, a few cases have granted refornation where fraud or mistake in the integration was absent. Stafford v. California Canning Peach Growers, 11 Cal. 2d 212, 78 P.2d 1150 (1938) ; cf. Wolfe v. Morgan, 95 Cal. App. 656, 273 Pac. 64 (1928). But cf. Anderson v. Yousem, 177 Cal. App. 2d 135, 143, I Cal. Rptr. 889, 894 (1960).

A few recent cases from outside the United States have allowed reformation in cases where there was no fraud or mistake in integration. A. Roberts \& Co., Ltd. v. Leicestershire County Council, [1962] 2 W.L.R. 1000, noted in 77 L.Q. Rev. 313 (1961); Mouton v. Hanckom, 3 So. Afr. L.R. 35 (A.D. 1959), discussed in Buchanan, Relaxation of the Parol Evidence Rule, 76 S.A.L.J. 271 (1959). See generally, Hermann, Reformation and Rescission, [1960] IrL. L.F. 1. 
However, the general rule is that the Statute of Frauds will not prevent reformation. ${ }^{140}$ It seems that the requirement of clear and convincing proof necessary to gain reformation ${ }^{141}$ adequately replaces whatever certainty is supplied by the requirement of a writing. Similarly, in cases where the defrauded person is seeking enforcement of the false promise, the requirement that fraud must be shown by clear and convincing proof ${ }^{142}$ will counterbalance any uncertainty caused by the absence of a written promise.

It is perhaps an understatement to say that courts would have to stretch existing doctrines to enforce false promises. Reformation and specific performance are generally thought of as extraordinary remedies, and properly so. But where no other remedy is adequate; courts should not be constrained by the parol evidence rule. The granting of damages is a method of enforcing the false promise. If promises without conventional exchange consideration are enforceable because of detrimental reliunce, ${ }^{143}$ there is no apparent reason why false promises relied upon to the extent of signing a written contract should not be enforced. ${ }^{144}$ This may be seen more clearly if the stress is placed upon the substantive right to a remedy for fraud.

\section{F. Focus on Fraud}

Fraud is not an exception to the parol evidence rule. Since the application of the rule is predicated upon a validly formed contract, any evidence should be permitted that shows a defect of formation. Yet the remedies available to the defrauded party extend beyond those logically resulting from the rationale that no contract existed. Ignoring for the moment actions for damages, it is clear that the defrauded party in some situations has been allowed a remedy amounting to enforcement of the promise. This can be justified by regarding the establishment of fraud as opening up a flexible set of remedies. ${ }^{145}$ The remedy need not be restricted

140 See Dawson \& Patmer, Cases on Restitution 745-46 (1958).

141 C.S. Foreman Co. v. Great Lakes Pipe Line Co., 274 F.2d 61 (8th Cir. 1960). See Restatesient, Contracts $\$ 511$ (1932).

1429 WrgMrore, EVIDENCE $\$ 2498$ (3d ed. 1940). See also Strand v. Librascope, Inc., 197 F. Supp. 743 (ED. Mich. 1961).

143 Restatearent, Contracts $\$ 90$ (1932).

144 Cf. City \& Westminster Properties v. Mudd, [1958] 2 All E.R. 733 (Ch. Div.). Here a landlord sued his tenant for damages. The tenant claimed he was told he could use the premises to hive in, but that it could not be put in the lease because it would run afoul of the Rent Restriction Act. The court rejected several arguments by the tenant, including reformation and waiver, but held for the tenant on an estoppel theory. There was no mention of fraud or the parol evidence rule. On the use of estoppel in England, see Combe v. Combe, [1951] 2 K.B. 215.

145 See Ward v. Taggart, 51 Cal.2d 736, 336 P.2d 534 (1959); Farina v. Bevilacqua, 192 A.C.A. 719, 723, 13 Cal. Rptr. 791, 793 (1961) (fraud; partial rescission allowed). See also UNIFORM COATIERCIAL CODE \$2-721:

Remedies for material misrepresentation or fraud include all remedies available under this Article for nonfraudulent breach. Neither rescission or a claim for rescission 
to one that is consistent with the method by which the evidence is admitted. In other words, the stress must be upon promissory fraud as a cause of action, rather than as a minor aspect of the total picture of the parol evidence rule. ${ }^{146}$ If this is recognized, then a remedy should be given that fits the circumstances, even if it means enforcement of the false promise.

Recognition that relief from fraud is the primary issue will produce several beneficial results. First, it will be possible to predict more soundly what a court will do when evidence of promissory fraud is offered, if the factors that go into the determination of fraud are weighed carefully. Some of these factors are:

1. Does the evidence tend to support the charge that the fraudulent promise was made? ${ }^{147}$

2. What is the reputation of the alleged defrauding party for fair dealing? ${ }^{148}$

of the contract for sale nor rejection or return of the goods shall bar or be deemed inconsistent with a claim for damages or other remedy.

The Comment to this section states that its purpose is: "to correct the situation by which remedies for fraud have been more circumscribed than the more modern and mercantile remedies for breach of warranty."

146 In Beers v. Atlas Assur. Co., 215 Wis. 165, 197-98, 253 N.W. 584, 597 (1934), Wickhem, J., stated:

Assuming that promissory misrepresentations may in any case be the ground for fraud, does the fact that the oral promise is identical with the stipulation in the writing throw the case within the prohibitions of the parol-evidence rule? I do not think it does, and it is iny conclusion that this is true whether the action be based upon an affirmance or disaffirmance of the contract. Here there is no attempt to vary, modify, or contradict the terms of the writing, nor is there any attempt to add to the contract by contemporaneous oral agreements. The charge is simply that a stipulation in the contract was made with the intent not to perform it. In this class of cases I see no relation between the parolevidence rule and the question of promissory fraud. If fraud cannot exist under these conditions, it must be because one who enters into a contract ought to be precluded from relying upon anything but the stipulations in the contract, upon some doctrine that any prehiminary oral negotiations have been merged into the contract and have entirely lost their legal materiality.

The same idea was expressed by Thayer when he discussed some of the supposed exceptions to the parol evidence rule such as fraud and stated:

all these questions, and many more of the same sort, although persistently thrown into the form of whether parol evidence be admissible for sucb purposes, really present no point in the law of evidence. The true inquiry is, whether certain claims or defenses be allowable. If relief can be had in such cases, the law of evidence bas nothing to say as to any kind of evidence, good under its general rules, which may be offered to prove these things. In so far as extrinsic facts are a legal basis of claim or defence, extrinsic evidence is good to prove them. Thayer, A Preliminary Treatise on Evidence at the Common LAW 409 (1898).

147 See McCreight v. Davey Tree Expert Co., 191 Mimn. 489, 254 N.W. 623 (1934); Berry v. Richfield Oil Corp., 189 Ore. 568, 220 P.2d 106 (1950).

148 Because of bad reputation, there are very few cases involving sales of personal property that do not permit the evidence. This is especially apparent in sales of automobiles, implements to farmers, and certain "fast sell" service contracts such as insulation, roofing, and siding. 
3. Is there any plausible reason given for the discrepancy between the claimed agreement and the writing ${ }^{149}$

4. What is the relative bargaining power of the parties?

5. Is it reasonable to expect the parties to have protected themselves in the writing? ${ }^{150}$

6. How compatible are the alleged oral promises and the writing ${ }^{161}$

In addition to these factors, consideration should be given to the following questions:

1. What attitude is the court taking in balancing the competing social policies embodied in the law of fraud and the parol evidence rule? ${ }^{152}$

${ }^{149}$ See Shyvers v. Mitchell, 133 Cal. App. 2d 569, 284 P.2d 826 (1955) (to satisfy bank examiners); Schupp v. Davey Tree Expert Co., 235 Mich. 268, 209 N.W. 85 (1926) (to satisfy agent's principal); City \& Westminster Properties v. Mudd, [1958] All E.R. 733 (Ch. Div.) (to avoid limitations of Rent Restriction Act).

Even when there is a reasonable explanation, this may be countered by the experience of the parties and the absence of an allegation of fraud. Rock-Ola Mfg. Corp. v. Wertz, 282 F.2d 208 (4th Cir. 1960).

If there is no excuse, it is likely to lead to a refusal by the court to admit the evidence. Bank of America Nat'l Trust \& Sav. Ass'n v. Lamb Fin. Co., 179 Cal. App. 2d 498, 3 Cal. Rptr. 877 (1960); cf. Rome v. New River Lodge Co. 402, 197 So. 174 (La. App. 1940).

Of course, if the reason is contrary to public policy the court may refuse to consider it. Shaw v. McCaslin, 50 Cal. App. 2d 467, 123 P.2d 102 (1942) (to avoid corporation law); Eason v. Thomas, 208 Ga. 822, 69 S.E.2d 729 (1952) (to avoid Bankhead-Jones Farm Tenant Act).

150 Here courts frequently look at whether the parties were represented by counsel and the busmess experience of the proponent of the evidence. A few cases noting the experience of the parties are Floyd v. Tierra Grande Dev. Co., 51 Cal. App. 654, 197 Pac. 684 (1921); Rome v. New River Lodge No. 402, 197 So. 174 (La. App. 1940); England v. Houser, 178 Mo. App. 70, 163 S.W. 890 (1914); Martin v. Harris, 121 Neb. 372, 236 N.W. 914 (1931); Ernst Iron Works v. Duralith Corp., 270 N.Y. 165, 200 N.E. 683 (1936) ; Winoka Village v. Tate, 16 N.J. Super. 330, 84 A.2d 626 (1951); Dahath Elec. Co. v. Suburban Elec. Dev. Co., 332 Pa. 129, 2 A.2d 765 (1938); Zettlemoyer v. Bloch, 329 Pa. 205, 198 Atl. 80 (1938).

That the person claiming fraud was represented by counsel was noted in Newmark v. H \& H Prod. Mfg. Co., 128 Cal. App. 2d 35, 274 P.2d 702 (1954); Keeler v. Fred T. Ley \& Co., 65 F.2d 499 (1st Cir. 1933) (by dissent); Beers v. Atlas Assur. Co., 215 Wis. 165, 253 N.W. 584 (1934).

But in Shyvers v. Mitchell, 133 Cal. App. 2d 569, 284 P.2d 826 (1955), the evidence was allowed despite the testimony by the guarantor that before signing he had consulted an attorney who advised lim that if the promise was not in the note, lie liad better be ready to pay.

151 See concurring opimion of Fairchild, J., in Beers v. Atlas Assur. Co., 215 Wis. 165, 190-91, 253 N.W. 584, 595 (1934):

A distinction should be noted here between the present case and one where the provision in the written contract is so directly in conflict with the oral promise as to put plaintiff on his guard. I agree with the majority that generally in such a case relief should be denied. I believe, however, that such denial should be based on the fact that the party did not rely upon the oral stateinent, or if le did, that he was entirely unwarranted in doing so, and not on an invocation of the parol-evidence rule. (Emplrasis added.)

152 Compare Bates v. Southgate, 308 Mass. 170, 182, 31 N.E.2d 551, 558 (1941), with Creasy Corp. v. Dunning, 182 Wis. 388, 397, 196 N.W. 775, 778 (1924). 
2. Is there a special need for security of writings in any given commercial transaction? ${ }^{163}$

3. How drastic a remedy is requested? ${ }^{154}$

4. Will the rights of third parties or the public be adversely affected by giving effect to the promise? ${ }^{155}$

Careful evaluation of these factors should lead to sounder predictions of whether the court will receive the evidence in the first instance, and whether ultimately it will lead to an evidence-supported finding of fraud.

Second, stressing the substantive law of fraud will help to reconcile the many cases that ignore the parol evidence rule. It is not uncommon to see a court distinguish holdings in similar fact situations because the prior case did not consider the parol evidence rule. ${ }^{156}$ Instead of receiving this treatment, these cases should be relevant precedents, since the parol evidence rule is not material to the question of promissory fraud.

Third, a greater recognition of the need to give relief from fraud will result in the admission of more evidence. Traditionally, courts have been liberal in admitting evidence of fraud, because it is usually so difficult to

153 In the cases studied the greatest resistance to the introduction of evidence of fraud was seen in actions on promissory notes. See, e.g., Steiner Bros. v. Slifkin, 237 Ala. 226, 186 So. 156 (1939) ; Bank of America Nat'l Trust \& Sav. Ass'n v. Lamb Fin. Co., 179 Cal. App. 2d 498, 3 Cal. Rptr. 877 (1960) ; People's Bank of Ava v. Baker, 193 S.W. 632 (Springfield Court of App. 1917) ; First Nat'l Bank v. Sagerson, 283 Pa. 406, 129 Atl. 333 (1925) ; Lanius v. Sluuler, 77 Tex. 24, 13 S.W. 614 (1890). A typical case is Stevens v. Inch, 98 Kan. 306, 308, 158 Pac. 43, 44 (1916) where the court stated:

It does not help the defense to call the statements and promises of Stevens fraudulent. The books teem with cases involving oral promises that notes need not he paid, or are inere memoranda, or will be surrendered without satisfaction, or may be paid out of the profits of a business venture if successful, and need not be paid otherwise. In all such cases the promise is made to induce the maker to sign the note and if the promise be not kept, it works a fraud. The theory of the law is that more fraud would result if all notes were open to qualification and contradiction by parol evidence than if the door were closed and locked against such evidence. Consequently, to defeat liability on a note because obtained by fraud, the fraud must consist in something else than representations and promises of the kind referred to.

Yet the Kansas Court took a different attitude in a similar case where the defrauded person was a Mexican who was deceived when he bought land. Stapleton v. Mendoza, $174 \mathrm{Kan} .468$, 257 P.2d 113 (1953).

154 Compare Sabo v. Delman, 3 N.Y.2d 155, 143 N.E.2d 906 (1957), with Cohen v. Cohen, 1 A.D.2d 586, 151 N.Y.S.2d 949 (1956), affd without opinion, 3 N.Y.2d 813, 166 N.Y.S.2d 10 (1957) (Fuld and Froessel dissenting) and Danann Realty Corp. v. Harris, 5 N.Y.2d 317, 184 N.Y.S.2d 599, 157 N.E.2d 597 (1959). All three cases involved disclanner of reliance clauses. The latter two were for damages, the former was for rescission. Although the cases stressed the varying degrees of specificity of the clauses, the remedy played a part in the results.

In Califormia the two leading cases rejecting evidence of promissory fraud were "rewriting of contract" cases rather than rescission. Bank of America Nal Trust \& Sav. Ass'n v. Pendergrass, 4 Cal. 2d 258, 48 P.2d 659 (1935); Cobbs v. Cobbs, 53 Cal. App. 2d 780, 128 P.2d 373 (1942).

155 See notes 133 and 149 supra.

150 Newmark v. H \& H Prod. Mfg. Co., 128 Cal. App. 2d 35, 274 P.2d 702 (1954). 
prove. ${ }^{157}$ This liberality must be balanced, of course, by better procedural devices to protect parties against false allegations of fraud. Unfounded and misleading cliarges of fraud have been a too frequent adjunct of the parol evidence rule. Both parties will be better protected if the courts, aware of the nature of the action as one for fraud, combine liberal admission of evidence with a leavy burden of proof.

\section{CONCLUSION}

I have attempted to demonstrate that California's restrictive rule regarding the admission of evidence of promissory fraud was conceived in error, is unjustifiable, and should be overruled. ${ }^{158}$ The California experience demonstrates that even where a restrictive rule is adopted, many devices will develop to avoid its impact. Even so, it is capable of preventing the victim of fraud from obtaining relief.

Once the evidence is admitted and the fraud is shown by clear and convincing proof, the defrauded party should have available a flexible arsenal of remedies. If justice requires, the false promise should be enforced. The focus should be placed upon the right to relief from fraud and the policies that support that right, rather than on fraud as a minor aspect of the parol evidence rule.

157 First Nat'l Bank v. Harvey, 29 S.D. 284, 137 N.W. 365 (1912) (great latitude is permitted in the introduction of evidence) ; Cattle Raisers' Loan Co. v. Sutton, 271 S.W. 233 (Tex. Civ. App. 1925) (broadest and most liberal rule of investigation is allowed). See also JoNEs, The LAW of Evidence IN Crvil Cases 547 (1912), where the author states: "No rule is better settled than this,- where fraud is alleged, a very broad range is given to the testimony."

158 At the very least, Pendergrass should be restricted to rewriting situations, and the true non-enforcement cases should be controlled by Langley v. Rodriguez, $122 \mathrm{Cal}$. 580, 55 Pac. 406 (1898), discussed in text at note 20 supra. 